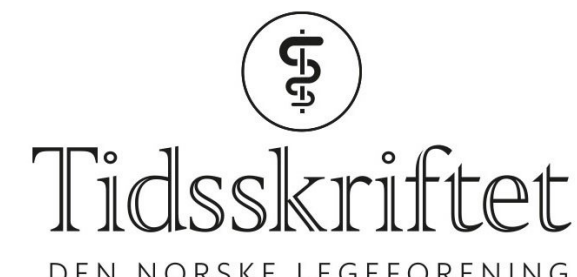

DEN NORSKE LEGEFORENING

\title{
Selvmord i litteraturen
}

ANMELDELSER

\section{ØIVIND EKEBERG}

Spesialrådgiver, professor emeritus, Klinikk psykiske helse og avhengighet Oslo universitetssykehus

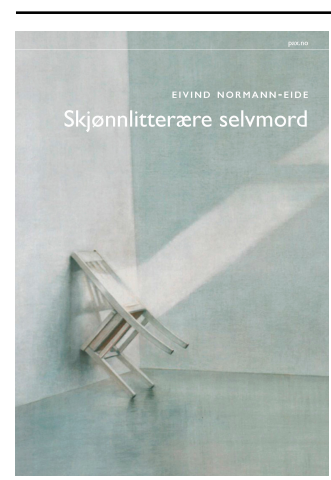

Eivind Normann-Eide

Skjønnlitterære selvmord

161 s. Oslo: Pax forlag, 2016. Pris NOK 349

ISBN 978-82-530-3913-8

Eivind Normann-Eide har i mange år arbeidet med pasienter med selvmordsatferd og med etterlatte etter selvmord. Han har erfart at det er stor variasjon i motiver og situasjoner ved selvmordsatferd. Forfatteren stiller spørsmål om også skjønnlitteraturen kan bidra til å belyse kjente risikofaktorer for selvmord og gi en innsikt som berører. Derfor har han valgt å skrive om noen bøker hvor selvmord omtales.

Boken er lettlest, og faguttrykkene er lett forståelige. Den består av en innledning med historier om selvmord, ti kapitler, et avslutningskapittel om skjønnlitterære selvmord og overlevelse, takksigelser, en oversikt over hvor man kan søke hjelp, noter og litteraturliste.

Det er en fin bredde i utvalget av litteratur. Første kapittel er om Den unge Werthers lidelser, som Goethe ga ut i 1774 da han var 25 år. Det er neppe tvil om at Goethe identifiserte seg mye med hovedpersonen, og hans beskrivelse av forelskelse, krenkelse og fortvilelse har bred aktualitet både på den tiden og i dag. Dette ble et spesielt viktig verk, fordi det var en opphopning av selvmord med samme metode blant unge menn i tiden etter at boken ble utgitt. Dette kalles for Werther-effekten, noe vi også er oppmerksomme på i dag.

I kapittel 2 omtales Tolstojs Anna Kareninas selvmord, som kom i bokform i 1878. Igjen er temaet kjærlighet, tap og sammenbrudd. Her skildrer Tolstoj det kvinnelige følelseslivet i sitt rike språk. 
I kapittel 3, Snø av den tyrkiske forfatteren Orhan Pamuk, beskrives et lukket muslimsk miljø, hvor flere unge kvinner tar livet sitt fordi de av myndighetene blir nektet å gå med religiøst hodeplagg på skolen.

Av nyere verker kan nevnes Sylvia Plaths Glassklokken og Eli Wurtzels Prozac Nation. Her er det mer dagsaktuelle temaer som beskrives, men man ser linjer også til de eldre verkene.

Normann-Eide lykkes godt med å binde de forskjellige litterære beskrivelsene til de mest kjente risikofaktorene for selvmord, både de demografiske og de psykologiske.

Mange av de litterære verkene er gamle. Det er interessant å lese litterære beskrivelser av de personlige konfliktene som førte til selvmord på en tid da det var tabubelagt å snakke om selvmord. Det er sannsynlig at forfatterne her lå foran fagmiljøet med hensyn til å forstå menneskesinnets kompleksitet.

Dette er ikke en fagbok som vil gi noen systematisk oversikt over risikofaktorer, behandling og forebygging av selvmord. Den vil imidlertid være av interesse for mange også utenfor det suicidologiske fagmiljøet som har interesse av psykologiske prosesser, spørsmål om liv og død og skjønnlitteratur.

Publisert: 21. august 2017. Tidsskr Nor Legeforen. DOI: 10.4045/tidsskr.17.0220

(C) Tidsskrift for Den norske legeforening 2020. Lastet ned fra tidsskriftet.no 